i mimo wyjazdu zaraz po pogrzebie do Gniezna na wspólne biskupie rekolekcje.

Dziękując Ci, Księże Biskupie za Twoją życzliwość, równocześnie na ręce Twoje wyrażamy nasze kondolencje $\mathrm{z}$ powodu śmierci ś.p. Ks. Biskupa A. Wronki. Czynimy to nie tylko, że nasz Zjazd rozpoczyna się w tym dniu, kiedy. Wrocław jest w żałobie, ale czynimy to $z$ potrzeby serca. Sp. Ks. Biskup A. Wronka to nasz starszy Kolega, Biblista. Na Poznańskim Uniwersytecie u Prof. Smieszki zdobywa doktorat na podstawie pracy Jahwe nomen ineffabile, następnie w Gieźnie i Poznaniu przez 23 lata wykłada języki biblijne i różne dyscypliny biblistyczne, a chociaż potem administracja najpierw w Kolegium Polskim w Rzymie, gdzie pełni obowiązki rektora, a później administracja Diecezją Gdańską, Chełmińską, a później sufragania we Wrocławiu nie pozwoliły mu pracować $\mathrm{w}$ dziedzinie biblijnej, to jednak lubił zawsze rozmowy i dyskusje z biblistami. Na pewno brałby udział w naszym Kongresie, gdyby śmierć nie zabrała go od nas. Ponieważ wielu Kolegów zwłaszcza starszych chciałoby wziąć udział w pogrzebie śp. Ks. Biskupa A. Wronki, dlatego nasze obrady zaprojektowane na godziny dopołudniowe odbędziemy po południu. Teraz zaś wszyscy podczas tej Mszy św. prosić będziemy Boga przez pośrednictwo Chrystus: o wieczny odpoczynek dla Jego duszy.

Nie zapomnijmy też o modlitwie za spokój duszy śp. Ks. Biskupa Latuska, który właśnie wtedy zmarł, gdy 11. II. 1973 r. przybyłem do Wrocławia, aby $\mathrm{z}$ nowomianowanym Kard. Kominkiem omówić nasz obecny Kongres.

Oprócz tych wdzięcznych wspomnień pro mortuis, pragnę też zachęcić do wdzięcznych wspomnień pro vivis. Do wdzięczności już wyrażonej Ks. Biskupowi W. Urbanowi, pragniemy wdzięczne memento uczynić za Zarząd Seminarium duchownego we Wrocławiu z Ks. Rektorem J. Majką na czele za to, że nas tutaj tak gościnnie przyjmują. Ponadto dołączamy wdzięczne memento za tych, którzy zgłosili referat czy komunikaty. Byłoby tych referatów czy komunikatów jeszcze więcej, ale z powodu późnego zgłoszenia Prezydium Kongresu nie mogło ich już włączyć do ustalonego wcześniej programu. Treść jednak tych referratów czy komunikatów poruszą z pewnością ich Autorzy w dyskusji i niechybnie oddadzą do publikacji w specjalnej Księdze tego Kongresu, która ma wyjść we Wrocławiu, aby była świadectwem jego powrotu do czołowych środowisk w świecie naukowym.

Do memento pro mortuis et vivis dołączamy gorącą prośbę do Boga przez Chrystusa Pana naszego, abyśmy z tych dni pracy podczas XII Kongresu wynieśli nowy zapał i nowe siły oraz nowe światła do prac wspólnych i indywidualnych, aby spełnić jak najlepiej ciążący na nas, biblistach, nakaz Jezusa, naszego Mistrza Scrutamini Scripturas.

\title{
PRZEMÓWIENIE KS. BISKUPA WINCENTEGO URBANA Z OKAZJI OTWARCIA XII KONGRESU BIBLISTÓW POLSKICH WE WROCEAWIU
}

Piękne są niewątpliwie dążenia duszpasterskie Kościoła świętego, zmierzające do tego, aby „Pismo święte dać do ręki najszerszemu ogółowi i aby nauczyć wiernych czytać objawioną skarbnicę praw Bożych", a przede wszystkim, aby spełnić najważniejsze zadanie duszpasterskich wysiłków, mianowicie nauczyć ludzi żyć Biblią świętą. Wysiłki te były trudne. Oceniano je niejednokrotnie $\mathrm{z}$ niedowierzaniem i rezerwą. Jest tu wśród nas 
polski biblista - ks. prałat Władysław Smereka, który tak szczerze i od dawna szerzył w społeczeństwie polskim urzekającą myśl rozbudzenia zapału czytania Pisma świetego. Miał i on opory na tej drodze. Przed rokiem 1935 szerzył on te myśli na gruncie lwowskim. Zapalał tą ideą alumnów lwowskiej uczelni, a nie wszyscy mu wierzyli.

Dziś wiele się zmieniło na tym polu. Wyrażamy wielką radość. Dziś Polska czyta Pismo święte. Miliony egzemplarzy Pisma świętego zawitało do polskich domów.

Pismo święte zawiera prawdy Boże. Ma ono bogatą treść życiową, pouczającą i praktyczną.

Kardynał Henryk Edward Manning (zm. 1892), najpierw zwolennik ruchu reformistycznego $\mathrm{w}$ łonie anglikanizmu, mającego na celu przywrócenie mu dawnej świetności i czystości starochrześcijańskiej, działającego przy uniwersytecie oksfordzkim, później kapłan, arcybiskup, cieszący się wynikami swych prac społecznych, mający wielkie uznanie, zwłaszcza u robotników londyńskich, jako pierwszą księgę miał Pismo święte, którą rano otwierał i ostatnią, jaką zamykał wieczorem. Z Pisma świętego czerpał on natchnienie do swych gruntownych nauk i wielkich dzieł.

Ruch biblijny rozwinął się słusznie w Kościele Katolickim i był on potrzebą chwili.

Fundamentem, na którym powstał ruch biblijny, były encykliki papieskie. Nie idzie nam w tym względzie o, ponowne odkrywanie Biblii w Kościele" czy ,odnowę biblijną", ale o wysiłki przyprowadzenia wiernych do ożywczych źródeł życia wewnętrznego i duszpasterskiego.

Wspaniały niewątpliwie impuls pod tym względem dała nam encyklika papieża Leona XIII Providentissimus Deus z roku 1893. Papież nawoływał w niej gorąco, aby otwarto ,,przesławne źródło katolickiego objawienia pewniej a obficiej dla pożytku Pańskiej owczarni”. Po przezwyciężeniu kryzysu modernistycznego nową encyklikę w tym duchu ogłosił papież Benedykt XV w 1920 roku Spiritus Paraclitus, w której zachęcał do czytania Pisma świętego. Papież ten pragnął, by Księgi święte weszły do rodzin chrześcijańskich tak, żeby wierni przyzwyczaili się czytać codziennie ewangelie, by je codziennie rozważali i uczyli się tym sposobem żyć pobożnie i zgodnie we wszystkim z wolą Bożą. Tenże papież jeszcze jako ks. Jakub della Chiesa założył ,Stowarzyszenie św. Hieronima” (Pia Societa di s. Girolamo), którego celem było szerzenie wśród wiernych Pisma świętego. Pojmował on to zagadnienie gruntownie i praktycznie.

Wspaniała postać papieża św. Piusa X i jego działalność przypominała, że ewangelia jest księga , wszystkich i dla wszystkich".

Szerokie horyzonty dla wykorzystania Pisma świętego w pracy duszpasterskiej otwarła encyklika Piusa XII Divino afflante Spiritu w 1943 roku.

Czytanie Pisma świętego przynosi człowiekowi niewątpliwie wielką kon rzyść. Jako najlepsza lelrtura kształci ono umysł, wyrabia władze duchowne, wprowadza człowieka w treść życia. Może my tu przytoczyć wzniosłe przykłady z życia świętych, wielkich postaci w Chrystusowym Kościele. I tak św. Augustyn miał usłyszeć słowa: ,tolle et lege”. Porwał tekst św. Pawła Apostoła podany w Liście do Rzymian (13, 12)" odrzućcież tedy uczynki ciemności, a obleczmy się w zbroję światłości". Umiał on ten wielki apel Boży dobrze wykorzystać w swym życiu. Pięknie kroczył w blaskach objawionej prawdy Bożej św. Tomasz z Akwinu, wielki jałmużnik - Św. Wincenty a Paulo, przyjaciel młodzieży - sw. Jan Bosco. Oni umieli trafnie odczytać Chrystusowe słowa: „chodź za mną".

Czytanie Pisma świętego pomnaża w czlowieku łaskę Bożą, uczy lepiej poznawać Chrystusa, gładzi grzechy lekkie, chroni od ciężkich przewin. 
Szkoda, że ostatnio usunięto z naszego życia $\mathrm{z}$ akcji liturgicznych piękne zdania i stwierdzenia: ,per evangelica dicta deleantur nostra delicta, evangelica lectio sit nobis salus et protectio". Lektura Ksiąg świętych uczy nas dobrego życia. Sprawia radość w duszy. Daje rękojmię przyszłej chwały.

Jeszcze jedno. Teologia czytania Pisma świętego przypomina, że posiada ono niezrównaną moc do poruszania i rozgrzania serc ludzkich, do rozbudzenia pięknych i trwałych uczuć religijnych.

$\mathrm{Na}$ tym tle jasny jest wniosek, że wiernych trzeba nauczyć czerpać łaski z tego źródła Bożego objawienia, jakim jest Pismo święte.

Warto tu przypomnieć znane słowa św. Hieronima, że „Ignoratio scripturarum - ignoratio Christi est”. Nie można też pominąć wypowiedzi św. Grzegorza I Wielkiego, że Pismo święte jest listem Boga do rodzaju ludzkiego, a czytanie jego ma być słuchaniem głosu Bożego, a nie szukaniem wiadomości.

W wiązance przytoczonych wypowiedzi autorytatywnych nie możemy jeszcze pominąć słów polskiego pisarza dawniejszych lat, mianowicie Eugeniusza Małaczewskiego, na temat 13 rozdziału św. Pawła Apostoła w Liście I do Koryntian, że ten rozdział jest ,płomiennym wichrem ducha, który przez ciąg stuleci wieje ogniem żywym i porywa się na nas w imię Miłości Najwyższej".

Witam wiẹc w prastarym Wrocławiu, bogatym w zasoby kultury katolickiej i polskich tradycji XII Kongres Biblistów Polskich. Słowa serdecznego powitania kieruję do naszych Gości z Wydziału Teologicznego w Erfurcie.

Życzę z całej duszy owocności obrad w tym naukowym spotkaniu. 